\title{
SWALLOW MORTALITY AT MOOSE MOUNTAIN
}

\section{by Spencer G. Sealy, Battleford}

A sudden onset of inclement weather during the period May 23 to May 26, 1965 , resulted in a mortality of swallows in the Moose Mountain Provincial Park in southeastern Saskatchewan. Four species were involved: the Tree Swallow (Iridoprocne bicolor), Bank Swallow (Riparia riparia), Barn Swallow (Hirundo rustica), and Cliff Swallow (Petrochelidon pyrrhonata). The first indication of this oncoming mortality came on May 26 when Ross Lein and myself observed swallows (largely Bank Swallows) seeking shelter in shallow burrows excavated in a low roadside cutbank near Clarke's Resort (see photo). Light snow had fallen early that morning, accompanied by a temperature low of $27^{\circ} \mathrm{F}$., while the maximum temperature reached during the day was only $37^{\circ} \mathrm{F}$, far below the $63^{\circ} \mathrm{F}$. recorded on this date in 1964. Close examination showed that a form of torpor had been assumed by many of the swallows, making it possible for some to be caught by hand; the birds removed from the burrows revived and flew with their usual skill, a phenomenon also recorded by Lorenz (1932) and McAtee (1947). Swallows were continually flying between the cutbank and Kenosee Lake, a distance of about 500 yards, where a large flock had formed over the water to search for insects.

On May 27 at the cutbank near Clarke's Resort, 27 Bank Swallows and one Tree Swallow were found dead; some were on the ground beneath the burrow entrances, but most were huddled together in the short burrows. Subsequently 46 more swallows were found dead at various locations in the park (see Table 1). The Barn Swallows and one Cliff Swallow had sought shelter under the eaves of camp kitchens where they perished; one Tree Swallow died under the eaves of the Chalet.

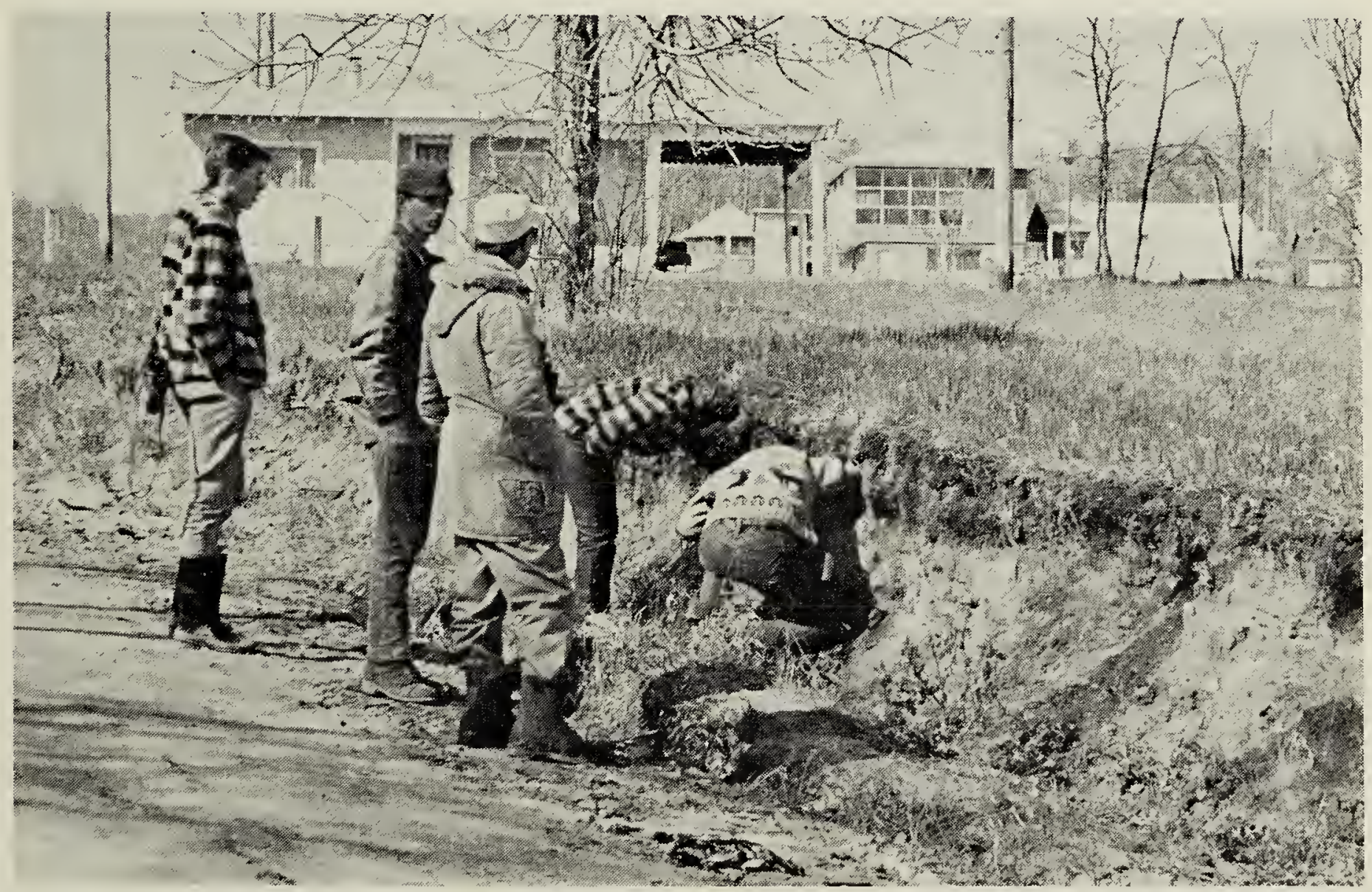

Photo by Robert R. Taylor

Temporary refuge site used by swallows 
TABLE 1.

Swallow mortality in Moose Mountain Provincial Park, Saskatchewan, following unseasonable weather in May, 1965.

\begin{tabular}{lcccl}
\hline Species & Date & $\begin{array}{c}\text { Number } \\
\text { Found Dead }\end{array}$ & $\begin{array}{c}\text { Average } \\
\text { Weight }(\mathrm{gm} .)\end{array}$ & $\begin{array}{c}\text { Location } \\
\text { in Park }\end{array}$ \\
\hline Tree Swallow & May 27 & 1 & $13.8(1)^{*}$ & Clarke's cutbank \\
Tree Swallow & May 27 & 1 & $\ldots \ldots \ldots$ & Chalet \\
Bank Swallow & May 27 & 27 & $11.5(14)$ & Clarke's cutbank \\
Bank Swallow & May 27 & 1 & $10.0(1)$ & Cabin \\
Bank Swallow & June 4 & 11 & $\ldots \ldots \ldots \ldots$ & Gravel pit \\
Barn Swallow & May 28 & 22 & $13.6(6)$ & Camp kitchens \\
Cliff Swallow & May 28 & 1 & $16.4(1)$ & Camp kitchen \\
Cliff Swallow & June 4 & 10 & $\ldots \ldots \ldots$. & Gravel pit
\end{tabular}

* Number in sample.

\section{TABLE 2.}

Temperature and precipitation (Rainfall and snowfall in inches) for May, 1964 and 1965, in Moose Mountain Provincial Park, Saskatchewan.

(Figures in parenthesis are those for 1964).

\begin{tabular}{lcccc}
\hline Period & $\begin{array}{c}\text { Mean Max. } \\
\text { Temp. }\left({ }^{\circ} \mathrm{F} .\right)\end{array}$ & $\begin{array}{c}\text { Mean Min. } \\
\text { Temp. }\left({ }^{\circ} \mathrm{F} .\right)\end{array}$ & $\begin{array}{c}\text { Mean Temp. } \\
\left({ }^{\circ} \mathrm{F} .\right)\end{array}$ & Precipitation \\
\hline May 1-30 & $60.8(64.0)$ & $35.4(39.6)$ & $48.1(5.1 .8)$ & $3.11(3.30)$ \\
May 1-23 & $62.7(64.4)$ & $35.2(41.8)$ & $48.9(53.1)$ & $1.75(3.30)$ \\
May 24-26 & $47.6(68.7)$ & $34.6(40.6)$ & $41.1(54.6)$ & $1.84(0.00)$ \\
May 26 & $36.0(63.0)$ & $27.0(40.0)$ & $31.0(51.5)$ & $0.95(0.00)$
\end{tabular}

According to Huxley et al (1939) torpidity, a temporary poikilothermy, is promoted by numerous factors; two which appear to be acting here are low temperatures, and consequently, a lack of food. Swallows are insectivorous, foraging only on the wing, therefore sudden inclement weather as was experienced here (see Table 2) would cause most of the flying insects to disappear, thus greatly depleting their food supply. As hunger becomes more critical at low temperatures due to higher general metabolism, more energy is required to maintain a constant body temperature (Kendeigh, 1945). Thus, as more energy, obtained from food, is required during a period of low temperature these birds suffer when their sole food supply is lacking. According to Kendeigh (1944) this energy for increased metabolism must come from the body reserves, chiefly fats, and the extent of these reserves is important in the bird's ability to tolerate low air temperatures for any length of time. The swallows are meanwhile utilizing the energy they have flying around seeking insects in vain. It would be interesting to compare weights of the swallows prior to perishing and after death to see if an appreciable weight loss had occurred.

These observations were made by Ross Lein, Richard Sanderson and myself while engaged in a survey of the birds of Moose Mountain under the direction of Dr. Robert W. Nero.

I should like to thank Mr. R. T. Douglas, officer in charge of the Meteorological Observing Station, Broadview, Saskatchewan, for his cooperation in supplying the weather data used in this report.

\section{LIT'ERATURE CITED}

Huxley, J., C. S. Webb, and A. T. Best. 1939. Temporary poikilothermy in birds. Nature, $143: 683-684$.

Kendeigh, S. C. 1944. Effect of air temperature on the rate of energy metabolism in the English Sparrow. Jour. Exp. Zool., 96:1-16.

Kendeigh, S. C. 1945. Resistance to hunger in birds. Jour. Wildl. Mgt., 9:217-226.

Lorenz, K. 1932. Beobachtungen an Schwalben anlaszlich der Zugkatastrophe in September 1931. Der Vogelzug, 3(1):4-10.

McAtee, W. L. 1947. Torpidity in birds. Am. Midl. Nat., $38: 191-206$. 